\title{
Director Connections in the Mutual Fund Industry
}

\author{
Paul Calluzzo*
}

First Draft: December 17, 2011

This Draft: February 25, 2012

*Calluzzo is from Rutgers Business School. I am grateful to Simi Kedia and Ankur Pareek whose guidance has been indispensable to this paper. A special thanks goes to Laurence Mucciolo whose insight was vital to the early development of this paper. All errors and omissions within the paper are my responsibility.

Author's contact information:

Email: calluzzo@pegasus.rutgers.edu;

Telephone: +1-516-375-0652

Address: 45 Hawthorne Place, Manhasset, NY, 11030 


\title{
Director Connections in the Mutual Fund Industry
}

\begin{abstract}
This paper studies the impact of director-manager relationships on mutual fund performance. Mutual funds connect to publicly traded firms when a fund director is also an employee of a firm. I posit these relationships facilitate information flow from the director to the manager, impacting portfolio choices and investment returns. I find funds hold larger stakes in connected stocks, and earn higher returns around earnings announcements on these holdings. Specifically, following the formation of a director connection, funds increase their holdings of the connected stock by an average of 17.6 percent. With respect to returns, in the days around earnings announcements, the cumulative abnormal returns of held connected stocks exceed the cumulative abnormal returns of unheld connected stocks by 0.94 percentage points per announcement. In addition to information flow, funds can benefit from connections to publicly traded firms by securing profitable fund inflows. I find more connected funds experience higher levels of fund inflows. For each director connection, the fund increases its annual fund inflow by 1.53 percentage points. Overall, my results suggest that the impact of connected directors on mutual funds extends beyond their formal fiduciary responsibilities.
\end{abstract}




\section{Introduction}

The mutual fund late trading scandal of 2003 brought the importance of mutual fund oversight to the public's attention. Vital to protecting shareholder interests from the self-interests of the fund's management is the independent director. Federal law requires at least 50 percent of a fund's directors to be independent. From 2000 to 2008, the percentage of mutual fund boards with over 75 percent of board seats held by independent directors increased from 52 percent to 88 percent $^{1}$. However, boards dominated by independent directors can create unintended consequences. In the investing world, who you know can affect how you invest. Anderson, Mansi and Reeb (2004) report 56 percent of corporate directors are executives at other firms ${ }^{2}$. Thus, within mutual fund board rooms, fund managers get to know corporate executives.

This paper examines the professional network that exists within mutual funds among a fund's manager and its directors. A mutual fund becomes connected to a publicly traded firm when a director of the fund is simultaneously an employee of a publicly traded firm. Research shows that investors rely on geographical (Coval and Moskowitz (2001)), professional (Hong, Kubik and Stein (2005), Duan, Hotchkiss and Jiao (2011)) and social ((Cohen, Frazzini and Malloy (2008)) networks to acquire information that informs investment decisions. Being part of a network provides a comparative advantage in the acquisition of information, which in turn allows information about companies to flow along the path of least resistance to connected investors.

\footnotetext{
${ }^{1}$ Investment Company Institute, Overview of Fund Governance Practices: 1994 to 2008. http://www.ici.org/pdf/pub_09_fund_governance.pdf ${ }^{2}$ Anderson, Mansi and Reeb (2004) report the employment background of directors at S\&P 500 firms. To the best of my knowledge no previous paper reports data on the employment background of mutual fund directors.
} 
Directors who are employees of public firms are likely to possess private information about these firms (Cohen, Frazzini and Malloy (2008)). Mutual fund managers have a large incentive to obtain private information. If fund managers extract such information from directors, I hypothesize that mutual funds will place large bets on connected firms and achieve high returns on these holdings. To study this network, I assembled a unique dataset containing 4,165 distinct fund-firm director connections between 2000 and 2008.

The central finding of this paper is that the director network facilitates information flow from the connected firm to the fund, impacting portfolio choices and investment returns. Funds hold larger stakes in in-network connected stocks compared to out-of-network unconnected stocks. Specifically, I find that following the formation of a director connection, funds increase their holdings of connected stocks by an average of 17.6 percent $(t=2.92$. After controlling for fund and stock specific factors, conditional on a fund actively holding a stock, I find funds hold 7.99 percent $(t=7.00)$ larger stakes in connected stocks compared to unconnected stocks. With respect to investment returns, I compare the Cumulative Abnormal Returns (CAR) around quarter earnings announcements of held connected stocks, unheld connected stocks, and unconnected stocks. Depending on the specification, the quarterly CAR of the held connected stocks exceeds the quarterly CAR of unheld connected stocks by 0.78 percent to 1.55 percent ( $t=2.52$ to $t=3.81$ ). The quarterly CAR of held connected stocks exceeds the quarterly CAR of unconnected stocks by 0.84 percent to 1.17 percent $(t=3.08$ to $t=3.28)$.

A second aim of this paper is to identify alternative mechanisms through which the fund is able to accrue benefits from the director network. Mutual funds generate profits by charging shareholders a fixed percentage of the assets they invest. Thus, by increasing its assets under management (AUM), a 
fund will increase its profitability. Cohen and Schmidt (2009) find that mutual funds use reciprocating relationships with publicly traded firms to secure $401(\mathrm{~K})$ trusteeships, which in turn boosts their AUM. I hypothesize that the director network enables connected funds to acquire greater fund inflows than unconnected funds. The findings of this paper support this hypothesis, indicating that the impact of the director network extends beyond information flow. With respect to fund flows, after controlling for fund and firm specific factors, I find that for each firm to which the fund is connected, annual AUM inflows to the fund increase by 1.53 percentage points $(t=5.31)$. Furthermore, the network effect is concentrated in the connections the fund holds. I find for each connected firm the fund holds, the annual AUM inflow increases by 4.57 percentage points $(t=4.19)$, compared to 1.10 percentage points $(t=3.47)$ for each unheld connection. Furthermore I find held connections, but not unheld connections, reduce the probability of a fund experiencing large outflows. The stronger effect found in held connections may be because these connections proxy for stronger fund-firm relationships, or because the fund-firm relationships are reciprocatory, consistent with Cohen and Schmidt (2009).

This paper contributes to the literature studying the effect of information networks on investor portfolio choice and investment returns. To the best of my knowledge, this is the first paper to study the director network and its impacts on information flow. The director network is built on a more direct relationship than previously studied information diffusion networks.

The second contribution of this paper is to the mutual fund governance literature. This literature has focused on how various incentives impact a director's ability to carry out his fiduciary responsibilities to the fund, finding that factors which align director incentives with the shareholders (and away from the fund managers) allow the director to better execute his fiduciary responsibility 
(Tufano and Sevick (1997), Del Guercio, Dann and Partch (2003), Ferris and Yan (2007), Khorana, Tufano and Wedge (2007), Cremers, Driessen, Maenhout and Weinbaum (2009)). My paper adds to the fund governance literature by explicitly studying a non-fiduciary mechanism through which the directors influence fund performance.

The third contribution of this paper is to the literature examining the impact of fund-firm networks on AUM fund flows (Cohen and Schmidt (2009), Duan, Hotchkiss and Jiao (2011)). Cohen and Schmidt (2009) find that funds use connections to publicly traded firms to facilitate increases in AUM by being named the firm's $401(K)$ trustee. Furthermore they find that these relationships are reciprocatory; funds overweight their holdings in $401(\mathrm{~K})$ connected firms independent of any information effects. I find that director connections also affect fund flows. With respect to Cohen and Schmidt (2009), my result suggests that the director network may play in a role in $401(\mathrm{~K})$ and pension trustee appointments.

\section{$\underline{\text { I. Literature Review }}$}

Two distinct literatures inform this paper, works examining the impact of information networks on the portfolio choices and investment returns, and works examining the impact of mutual fund directors on fund performance and investment returns.

\section{The Impact of Networks on Mutual Funds}

This paper and Kuhnen (2009) link the fund governance and network literatures. Kuhnen (2009) focuses on the reciprocating relationship that exists between the fund adviser and directors. When a fund is created the fund adviser appoints the fund's original directors. Following the formation of the fund, the board of directors is responsible for overseeing and, if necessary, replacing the adviser. 
Kuhnen (2009) hypothesizes that this arrangement may lead to a quid pro quo between the director and adviser. To increase the likelihood of appointments to future positions, directors may curry favor with the adviser by neglecting their fiduciary responsibilities to the fund's shareholders. She finds directors and advisers are more likely to appoint each other if they have previous business relationships. With respect to fiduciary impacts, she finds that the strength of the adviser-director relationship is correlated with higher fund expense ratios, but the effect is not statistically significant. She conjectures that the negative effects of favoritism are counteracted by improved monitoring facilitated by the stronger director-adviser relationship. I expand upon her work by examining if the documented exchange of favors between the director and adviser extend to information and fund flows.

Cohen, Frazzini and Malloy (2008) study the network that forms when senior officers at public companies and mutual fund managers attend the same university. They find that funds hold larger stakes in connected stocks, and generate large abnormal returns from these holdings. My paper and Cohen, Frazzini and Malloy (2008) both study how fund-firm networks can affect the portfolio choices and investment performance of mutual funds. However, the two networks differ in the intensity and nature of their connections. Firm employees in the education network are not directly paid by the fund and no data exists on their level of fund ownership. In contrast, fund directors are directly paid by the fund and are often heavily invested in the funds they oversee. Ferris and Yun (2007) report the average independent mutual fund director earns $\$ 32,000$ per board appointment. Chen, Goldstein, and Jiang (2008) estimate the average director's ownership stake in the funds they oversee to be $\$ 267,000$. Thus, fund directors who facilitate information flow to the manger can be directly rewarded with additional lucrative board appointments, and increases in the value of their investments. 
Cohen and Schmidt (2009) study the fund-firm network that forms when a fund is the trustee of a publicly traded firm's $401(\mathrm{~K})$. They provide evidence that funds use the $401(\mathrm{~K})$ relationships to secure asset flows into the fund. They also find that connected funds significantly overweight their holdings in the firm's stock. Furthermore, they find $401(K)$ linked funds provide price support for the firm's stock. Around times of substantial selling by all other funds, the $401(K)$ linked funds purchase the firm's stock. They show the higher holdings are not associated with higher returns, implying this behavior is independent of information. The findings of Cohen and Schmidt (2009) imply that firms are willing to participate in a quid pro quo with mutual funds, where 401K trusteeships are exchanged for large stable institutional holdings. Applied to the director network, this finding implies that directors, acting as a proxy for their employing firm, may use the director network to court large stable institutional holdings for the firm, or other corporate visibility benefits. Additionally, funds may use the director network to court 401(K) business and increase their AUM flows. Duan, Hotchkiss and Jiao (2011) extend the findings of Cohen and Schmidt (2009) by examining the connections formed between firms and the fund families that manage their pension plans. Unlike Cohen and Schmidt (2009), Duan, Hotchkiss and Jiao (2011) find that an information exchange occurs between the fund family and firm. They find that the stocks connected firms sells experience low future returns, but connected purchases are not associated with increased returns. They conjecture this asymmetry is the result of pension business considerations dominating stock purchases, while information considerations dominating stock sales.

\section{The Impact of Directors on Mutual Funds}

A conflict of interest exists within mutual funds. They are required to maximize profits for their outside owners, while minimizing the costs charged to shareholders. The primary purpose of the 
director is to mitigate this agency problem by serving a fiduciary role within the fund. They are formally responsible for "approving the funds major contracts with service providers (including, notably, the fund's investment manager), approving fund policies and procedures to ensure the fund's compliance with federal securities laws, and undertaking oversight of the performance of the fund's operations ${ }^{3 \prime}$. Previous research has focused on how the incentives directors face impact their ability to carry out their fiduciary responsibilities. My paper adds to this literature by expanding this analysis to the director's impact on the fund's investment decisions. With respect to fiduciary responsibilities, directors act as arbitrators in a zero sum game between the fund's shareholders and the fund's adviser. With respect to investment performance, however, shareholder and adviser interests are aligned; high returns benefits both parties. Incentives that previous research has shown lead directors to act against the shareholders interest with respect to fiduciary responsibilities, will not necessarily have the same impact on investment performance. Instead, any factor that aligns director interests with the shareholder or the manager, should improve information flow from the director to the manager.

The SEC takes several steps to insure that director interests are aligned with the shareholder. They require mutual funds to disclose the independence, employment history, tenure, number of funds overseen, compensation and fund ownership of the fund's directors. Furthermore, under the Investment Company Act of 1940, mutual funds are required to have a board composed of at least 40 percent independent directors, and only the independent directors of funds are allowed to select and nominate future independent directors. The director nomination process is particularly relevant to the alignment of director interests. When a mutual fund is first formed, the fund adviser selects the initial

\footnotetext{
${ }^{3} 2011$ Investment Company Institute Factbook. http://www.icifactbook.org/fb_appa.html
} 
independent board members of the fund. This insures none of the initial directors are truly independent. Furthermore, the initial independent directors are responsible for nominating future independent directors, ensuring no director is ever truly independent of the fund adviser.

The fund governance literature studies the effect SEC defined independence, director compensation, tenure and fund ownership have on the director's ability to carry out their fiduciary responsibilities. This research finds the presence of SEC defined independent directors improve the quality of mutual fund governance as measured by expense ratios (Tufano and Sevick (1997), Del Guercio, Dann and Partch (2003), Ferris and Yan (2007)), the willingness to accept value enhancing restructurings and mergers (Khorana, Tufano and Wedge (2007)), and the probability of being implicated in a fund scandal (Ferris and Yan (2007)). With respect to director compensation, the research supports the notion that director compensation can be seen as a proxy for potential adviser influence over the board of directors. Tufano and Sevick (1997), Del Guercio, Dann and Partch (2003) and Ferris and Yan (2007) find that increased director compensation is associated with higher shareholder fees. Ferris and Yan (2007) provide evidence that the probability of a fund scandal is positively related to independent director compensation.

Del Guercio, Dann and Partch (2003) conjecture that the length of the relationship between adviser and director may hinder the director's ability to remain objective, because over time the interests of the director and the adviser become aligned. Empirically, Del Guercio, Dann and Partch (2003) and Ferris and Yan (2007) find that director tenure has no effect on fund expense ratios or the probability a fund is involved in a scandal. Ferris and Yan (2007) attribute this lack of an effect to the fact that tenure may also proxy for director experience which would have a positive effect on the fund. 
Cremers, Driessen, Maenhout and Weinbaum (2009) study the impact of director ownership of the fund on the performance of the fund. They find evidence that director ownership is positively related to fund performance, and funds with high levels of director ownership outperform those with low levels director ownership. They demonstrate that only a small part of this abnormal return is due to lower fees, indicating the director's influence on fund performance extends beyond fee levels. They conjecture that increased director ownership aligns the director and shareholder interests, improving the director's incentive to monitor the fund adviser. Within the framework of my paper, if information flow helps funds earn abnormal returns, directors who facilitate information flow to their fund and have ownership stakes in their fund will experience direct increases in their levels of wealth.

\section{Data}

To my knowledge, this is the first paper to study the fund-firm director network. As such, it was necessary to collect a unique database mapping all director connections. Previous research on mutual fund directors has relied mainly on hand-collected data, and as a result has been limited to small samples. The only feasible way to gather a large sample of director connections is through an automated data collection process known as Web Crawling. I use this method to search over 100,000 SEC filings for information about the employment history of mutual fund directors. This information is used to compile a comprehensive dataset mapping fund-firm director connections.

The first step in the data collection process was to identify the names of all mutual fund directors during the period 2000 to 2008 . This information was obtained from the Standard \& Poor's Capital IQ database. Each year mutual fund companies are required to disclose the names of all directors 
to the SEC in Form N-CSR (Form N-30D prior to 2003). There are approximately 4,000 N-CSR filings per year. I use a web crawler algorithm developed by Engelberg and Sankaraguruswamy (2007) to search for the director names [collected from Capital IQ] in all N-CSR filings from 2000-2008. The result of this algorithm is a database containing observations of year-fund company-director.

Next I identify the publicly traded firms that employ each mutual fund director. Public firms are required to disclose the names of their directors and executive officers to the SEC in Form 10-K. Each year there are approximately 10,000 10-K filings. I use the Engelberg and Sankaraguruswamy (2007) web crawler algorithm to search for mutual fund director names in each Form 10-K filing. The result of this algorithm is a database containing observations of year-public firm-director ${ }^{4}$. Merging the N-CSR and 10$\mathrm{K}$ web crawler databases by common year-director, results in the mapping of the fund-firm director network. For more detail on this process please see Appendix A. In total, the data collection process identifies 4,165 unique fund-firm director connections, averaging 1,360 connections per year as reported in Panel A of Table 1.

\section{(Insert Table 1 about Here)}

Next I merge the director network database with the Thomson Financial CDA/Spectrum Mutual Fund holdings database. This allows me to analyze which connected stocks connected funds hold. After filtering out foreign and non-equity funds, the sample contains 1,132 unique fund companies and 3,920 unique mutual funds. The fund company is the location of the board of directors, while the mutual fund is the location of the investment decision maker, the fund manager. A fund company oversees one or

\footnotetext{
${ }^{4}$ This data is supplemented with data from the Compustat Execucomp database which lists the full name of corporate executives, as well as the firm they work for and when they workedthere.
} 
more mutual funds. Thus, two mutual funds in the same fund company will have the same board of directors. In each year of the sample there are on average 792 fund companies and 2,509 mutual funds. Analyzing the holdings of mutual funds reveals that on average 212 fund-firm connections are held by the connected fund each quarter (See Panel A of Table 1).

Panel B of Table 1 reports data on a per board basis. The data collection process identifies 5.82 independent directors per board. This figure is consistent with previous studies of mutual fund boards ${ }^{5}$. With respect to the director network, each board is connected to 1.72 publicly traded firms ${ }^{6}$. Of these connections the average mutual fund holds 0.14 connected stocks.

\section{(Insert Table 2 about Here)}

Panel A of Table 2 presents data describing the scope of the director network. Each year 3.93 percent of stocks in the CRSP universe are connected to a fund, representing 14.86 percent of the outstanding CSRP market capitalization. With respect to connections held, 1.09 percent of the stocks in the CRSP universe are held by a connected fund each quarter, representing 7.82 percent of the outstanding CRSP market capitalization. Over 50 percent of all identified connections are eliminated by robustness checks [described in Appendix A] to insure the sample does not include spurious connection. As a result, I expect the true scope of the director network to be larger than the summary statistics report.

\footnotetext{
${ }^{5}$ Using a hand collected sample of the 448 fund boards from 2002, Ferris and Yun (2007) report an average of 4.52 independent directors per board. The Investment Company Institute reports an average of 6 independent directors per board as of 2008. I expect some discrepancy between the characteristics of my sample and those of past research due to differences in the sample (funds analyzed and time period) and data collection method.
} 
Panel B of Table 2 presents summary statistics describing the size of connected firms. The average market capitalization of connected firms (\$9.06B) was larger than the average size of CRSP firms held by the mutual fund universe $(\$ 1.94 \mathrm{~B})$. It is not surprising that connected firms are larger than unconnected firms. Large firms have more employees, and their employees are more prestigious as potential directors compared to the employees of small firms.

\section{Results: The Director Network and Mutual Fund Portfolio Choice}

If the director network impacts the investment decisions of mutual fund managers, the portfolio choices they make in connected stocks will differ from the portfolio choices the fund managers make in unconnected stocks. Specifically, if managers extract private information from directors, mutual funds will hold higher levels of the connected firm's stock to profitably exploit this information. Thus, establishing that the director network impacts mutual fund holdings is an important first step in establishing that the director network facilitates information flow.

Holdings of Connected Stocks: Connected Funds vs. Unconnected Funds

The funds that hold the stock of each publicly traded firm can be partitioned into two groups, funds that are connected to the firm through the director network and funds that are not connected to the firm. Table 3 uses paired t-tests to test the null hypothesis that the difference in holdings of connected stocks by connected funds and unconnected funds is equal to zero. I use two different measures to gauge the level of fund holdings in a stock, "Percent Held" and "Portfolio Weight". Percent Held, is the proportion of connected and unconnected funds holding a given stock. If 10 Funds are connected to Stock B in the first quarter of 2005, and two of the funds held Stock B, the Percent Held statistic would equal $2 / 10$ or 0.20 . "Portfolio Weight," is the weight of a stock within a fund's portfolio. 
If the fund has $\$ 1,000,000$ in total holdings and holds $\$ 10,000$ of stock $A$, stock $A$ would have a portfolio weight of 1 percent. If multiple funds are connected to stock $A$, the Portfolio Weight measure is calculated by dividing their aggregate holdings of Stock A by their aggregate total holdings.

\section{(Insert Table 3 about Here)}

For both holdings measurements, the null hypothesis that connected funds and unconnected funds hold the same level of connected stocks can be rejected. The results indicate connected funds hold larger stakes in connected stocks than unconnected funds. The Percent Held measure is 0.55 percentage points greater for connected funds. This figure represents a relative increase of 11.07 percent, and is statistically significant $(t=4.21)$. Similarly, the Portfolio Weight measure is 0.004 percentage points $(t=2.41)$ greater for connected funds, representing a relative increase of 10.79 percent over unconnected stocks.

\section{$\underline{\text { Holdings Regression Analysis }}$}

Comparing the holdings of connected funds in connected stocks to the holdings of unconnected funds using univariate analysis may fail to control for fund specific factors that affect portfolio choice. For example, a value fund may be more likely to connect to a value stock, and hold larger stakes in value stocks. Table 4 presents the results of pooled OLS regressions which measure the effect of connections on holding size after controlling for these firm and fund specific factors. The regression considers all stocks that funds actively hold. The regression includes a variable, \%STYLE, to control for each fund's investment style. This variable measures the percentage of the fund's assets invested in the style corresponding to the stock being considered. The dimensions of style considered are value, size and 12month return momentum. Each dimension is measured in quintiles, resulting in 125 unique fund styles. 
The regression also includes controls for stock specific factors, specially variables that measure each stock's size, value, and 12-month return momentum ${ }^{7}$. Going forward this set of controls is termed "DGTW Controls". Additionally, fund and quarter fixed effects are included.

The unit of observation in the regression is the fund-firm-quarter. To evaluate the holdings size of stocks I use the Portfolio Weight measure as well as two additional benchmark-adjusted measures, "Market Tilt" and "Portfolio Tilt" previously employed by Cohen, Polk and Silli (2010). Market Tilt compares the Portfolio Weight of a stock in a given mutual fund to the market capitalization weight of the stock. For example, if a stock has a Portfolio Weight value of 2.0 percent in the fund's portfolio, and a 0.5 percent market capitalization weight, it would have a Market Tilt of 1.5 percent. Portfolio Tilt uses the market capitalization weighted portfolio of stocks contained in each fund's portfolio to create a fund-specific benchmark. Consider a fund that holds two stocks, stock A which has a market capitalization of $\$ 100$ billion, and stock $B$ which has a market capitalization of $\$ 50$ billion. The benchmark weight for stock A would be 100 billion/\$150 billion, or 66.7 percent. The benchmark weight of stock B would be $\$ 50$ billion/\$150 billion, or 33.3 percent. Each stock's Portfolio Tilt is then calculated by subtracting the stock's benchmark weight from the stock's Portfolio Weight. For more information on the construction of these benchmarks see Appendix B. As indicated, the dependent variable in each regression is the Portfolio Weight, Market Tilt or Portfolio Tilt measurement for each stock. The independent variable of interest is a dummy variable that identifies a stock as being connected. A positive coefficient for this variable indicates that funds in the director network hold larger levels of connected stocks.

\footnotetext{
${ }^{7}$ The DGTW benchmarks are available via

http://www.smith.umd.edu/faculty/rwermers/ftpsite/Dgtw/coverpage.htm
} 


\section{(Insert Table 4 about Here)}

The results presented in Table 4 support the hypothesis that when funds actively hold connected stocks, the holdings are larger than the active holdings of unconnected stocks. In all three specifications of the model the connected dummy variable is positive, ranging from 0.034 to 0.055 percentage points, and statistically significant $(t=2.21$ to $t=7.00)$. This represents a relative increase of approximately 8 percent.

\section{$\underline{\text { Holdings Around Connection Formations and Terminations }}$}

The results of the univariate and regression holdings analysis provide evidence that connected funds hold larger stakes in connected stocks. However, the analysis is not able to distinguish if this result is caused by the connections leading to increased holding levels in connected stocks, or because funds are more likely to connect to firms that they already have large holdings in. To control for causality, for each fund-firm connection, I focus on when the connection is first formed, and when the connection ends. If the presence of a director connection leads to increased holdings, I posit that after the formation of a connection, the fund's level of holdings in the connected stock will increase. Similarly, I posit that after the termination of a connection, the fund will decrease its holdings in the previously connected stock.

\section{(Insert Table 5 about Here)}

Panel A of Table 5 uses paired t-tests to test the null hypothesis that the difference in holdings before and after the formation of the direction connection is equal to zero. The average holding size for each fund-firm connection is computed using data from the eight quarters prior to and after the 
formation year of the connection. The year the connection is initiated is excluded from the analysis, as it is unclear when within the year the connection is formed. The results show that following the formation of a connection, the likelihood the fund will own the connected stock increases 0.80 percentage points $(t=2.57)$, and the Portfolio Weight of the stock increases 0.014 percentage points $(t=2.92)$. In relative terms this represents an economically significant 9.02 percent and 17.63 percent increase in the Percent Held and Portfolio Weight metric, respectively.

Panel B of Table 5 tests the null hypothesis that the difference in holdings before and after the director connection ends is equal to zero. Panel B uses the same methodology as Panel A, but focuses on connection terminations rather than formations. The results show that following the termination of a connection, the Percent Held measure decreases 0.69 percentage points $(t=-1.81)$, or 7.44 percent in relative terms. Similarly, the Portfolio Weight measure decreases 0.017 percentage points $(t=-2.78)$, or 22.02 percent in relative terms.

The results of the univariate, regression and formation/termination holdings analysis provide evidence that the fund-firm relationships formed through the director network affect the fund's portfolio choices. Mutual funds hold larger stakes in connected stocks compared to unconnected stocks. This result is a necessary but not sufficient condition in demonstrating the director network leads to information flow at mutual funds. In addition to information flow (Cohen, Frazzini and Malloy (2008), Duan, Hotchkiss and Jiao (2011)), research shows that familiarity bias (Huberman, 2001), and noninformation based network effects (Cohen and Schmidt ((2009)) can lead to outsized connected holdings. Based on the holdings results alone, it is not clear if the larger holdings of connected stocks are driven by information. 


\section{Results: The Director Network and Mutual Fund Returns}

Connected funds hold larger stakes in connected stocks, but why? A primary purpose of all mutual funds is to earn high returns for its shareholders. As directors are likely to possess information about the firms they work for, the most plausible explanation for the elevated levels of holdings in connected stocks is that managers extract private information from directors, and these elevated holdings represent the manager's attempt to profit from this information. If this explanation is valid, then the holdings of connected stocks, driven by private information, should produce abnormal returns. In sections that follow, I test this hypothesis by exploring the impact of the director network on the returns funds earn in connected stocks.

\section{Calendar Time Portfolio Returns}

This section uses a calendar time approach to investigate the returns of portfolios composed of held connected stocks, unheld connected stocks and unconnected stocks using a calendar time approach. By comparing the returns of the held connected portfolio against the returns of the alternative benchmark portfolios, I test the hypothesis that funds earn higher returns in connected stocks. Each quarter stocks are assigned to the appropriate portfolios. For example, consider two funds, Fidelity and Vanguard, and two firms, GE and IBM. Suppose Fidelity is connected to GE. Each quarter Fidelity actively holds GE's stock; this fund-firm holding will belong to the held connected portfolio. Each quarter Fidelity does not hold GE's stock; this fund-firm holding will belong to the unheld connected portfolio. Vanguard is not connected to GE or IBM, and Fidelity is not connected to IBM. Thus, any 
quarter Vanguard actively holds GE or IBM, or Fidelity holds IBM, the holding will belong to the unconnected portfolio.

Once all fund-firm holdings are assigned to the appropriate portfolio, the returns of the portfolios are calculated by weighting the returns of each stock within the portfolio by one of three weighting methods: "equal-weighted," "percent-weighted" and "dollar-weighted". The equal-weighted method assigns the same weight to each stock. In the equal-weighted method each stock is only counted once, a stock held by two funds receives the same weight as a stock held by one fund. While equally weighting stocks introduces the least bias, it is not representative of the manager's conviction in each holding. If a manager feels strongly about the future positive performance of a stock he will overweight the holdings of that stock. The percent-weighted and dollar-weighted portfolios attempt to capture the strength of a manger's conviction in the stock. The percent-weighted portfolio gives equal weight to each fund, but within each fund gives larger weight to stocks with higher holdings. The percent-weight of Stock $A$ is calculated by dividing the Portfolio Weight of Stock A in Fund B, by the Aggregate Portfolio Weights of all other stocks in the portfolio. The dollar-weighted method gives more weight to larger funds, and more weight to larger holdings within each fund. This weighting gives returns most similar to the returns of the entire mutual fund industry. The dollar-weight of Stock $A$ is calculated by dividing the dollar holdings of Stock A in Fund B, by the dollar holdings of all stocks in the portfolio. For more details on the construction of these weighting methodologies see Appendix B. Weighting the unheld connected portfolio presents a problem as there are no holdings to weight. The equal-weighted portfolio uses the same methodology as the connected and unconnected portfolios. For the percent-weighted and dollar-weighted methods, the weighting for the corresponding unconnected 
stocks are used to weight the unheld connected stocks. Thus, if Stock $A$ is an unheld connected stock and receives a 1 percent dollar weight in the unconnected portfolio, it would receive a 1 percent dollar weight in the unheld connected portfolio. The portfolios are rebalanced and the weights recalculated each quarter. Monthly returns are computed based on the assumption that funds do not change their holdings between quarters.

Returns are risk-adjusted using four-factor alpha adjusted returns and DGTW characteristic adjusted returns. The four-factor alpha is the intercept of an OLS regression of monthly portfolio returns minus the risk free rate on the monthly returns of the three Fama-French (93) factors (MKTRF, SMB, HML) and the Carhart (97) momentum factor. DGTW characteristic adjusted returns are computed for each stock by subtracting the return of a value-weighted portfolio of all CRSP firms in the same size, market-book, and 12-month momentum quintile from each stock's raw return ${ }^{8}$. The portfolio DGTW adjusted return is then computed by aggregating the adjusted return of each individual stock using the equal-weighted, percent-weighted and dollar-weighted methodologies.

\section{(Insert Table 6 about Here)}

Table 6 presents the results of the calendar time returns of the portfolio of held connected stocks (column 1). Furthermore, the table presents the returns of a trading strategy long in the portfolio of held connected stocks and short in the portfolio of unheld connected stocks (column 2), and long in the portfolio of held connected stocks and short in the portfolio of unconnected stocks (column 3). The results fail to provide evidence that the director network affects stock returns. The difference between

\footnotetext{
${ }^{8}$ Benchmark Portfolios are obtained from Russ Wermer's website. http://www.rhsmith.umd.edu/faculty/rwermers/
} 
the monthly risk-adjusted return of the held and unheld connected portfolios range from -0.3 percent to 0.1 percent and is never statistically significant. The difference between the held connected portfolio and the unconnected portfolio ranges from -0.1 percent to 0.2 percent and is never statistically significant.

Table 6 includes two additional benchmark portfolios which attempt to adjust for factors specific to the connected stock. If information is transferred through the director network I expect the returns of connected stocks by connected funds to exceed the returns of those same stocks held by unconnected funds (Column 4). For example, if Fidelity is connected to IBM, but Vanguard is not, the holdings of IBM by Fidelity would belong to the connected portfolio, while the holdings of IBM by Vanguard would belong to the unconnected funds/connected stocks portfolio. Furthermore, I expect the returns of connected stocks by connected funds to exceed the returns of connected stocks by the connected fund, but before and after the connection is formed (Column 5). Thus if Fidelity was connected to IBM in the years 2003-2008, the holdings of IBM by Fidelity in the years 2000-2002 would belong to the Connected Funds, Before/After Connection portfolio. This analysis helps to control for the possibility that the results are biased due to connected stocks as a whole experiencing high or low returns. The results of Table 6 show the connected portfolio fails to achieve greater returns than either of these benchmark portfolios. The returns of the connected portfolio exceed the returns of the portfolio composed of connected stocks held by unconnected funds in only 3 of the 6 specifications, ranging from -0.2 percent to 0.1 percent per month ( $t=-1.225$ to $t=0.69$ ). Similarly, the returns of the connected portfolio exceed the returns of the portfolio composed of connected stocks before and after 
the connection is formed in only 3 of the 6 specifications, ranging from -0.2 percent to 0.2 percent per month ( $t=-1.07$ to $t=0.70)$.

\section{$\underline{\text { Stock Returns Following Stock Purchases and Sales }}$}

When trying to gauge a manager's conviction in the future performance of a stock, changes in holdings, can be more informative than absolute levels of holdings. If a manager receives positive information about a stock, he will buy it, and vice versa. Thus, if managers extract information from connected directors and use the information when making their portfolio decisions, the returns of stocks following purchase should exceed the returns of stocks following sales.

Table 7 presents average monthly DGTW-adjusted returns of connected stocks following purchases and sales to test the hypothesis that the returns of connected stocks following purchases exceed the returns of connected stocks following sales. Each quarter the holdings of each connected stock are aggregated across all funds that hold the stock. After adjusting for price changes the difference in holdings quarter to quarter is then used to identify a stock as having experienced net buying or net selling activity. To weight the holdings of each stock in the purchased and sold portfolio, the equalweighted, dollar-weighted and percent-weighted methodologies are used. However, instead of weighting the absolute holdings, the unit of weighting is the change in holdings. Panel A of Table 7 presents the returns of connected stocks following stock purchases. Panel B presents the returns of connected stocks following stock sales. Finally, Panel C analyzes the difference between the two portfolios. Average monthly returns are presented over the following 1, 2, 3 and 4 quarters after the stock purchase or sale. 


\section{(Insert Table 7 about Here)}

Table 7 fails to provide evidence that connected stock purchases and sales predict future stock returns. Both connected purchases and connected sales tend to precede positive future stock returns. Panel A shows in 10 of 12 specifications, connected purchases produced positive future returns ranging from -0.08 percent to 0.52 percent per month, but was never statistically significant $(t=-0.16$ to $t=1.37$ ). Panel B shows the connected sales portfolio also produced positive returns in all 12 specifications comparable to the level of the connected purchases portfolio, and was never statistically significant $(t=0.10$ to $t=1.45)$. Panel $C$ shows connected purchases outperform connected sales in 7 of the 12 specifications of the model, ranging from -0.66 percent per month to 0.31 percent. The difference between the connected purchases and sales portfolio was never statistically significant $(t=-1.27$ to $t=0.89)$. Based on these results we cannot reject the null hypothesis that the returns connected stocks following purchases exceed the returns of connected stocks following sales.

\section{Earnings Announcement CAR}

If investors extract information from networks, they should make the majority of their returns when the private information that is transferred through the network is announced to the public. Cohen, Frazzini and Malloy (2008) confirm this intuition, finding 91 percent of the total connection premium earned in the education network was earned in the days surrounding corporate news announcements. Thus, focusing only on the returns of connected stocks in the days surrounding corporate announcements can disentangle price movements based on information that is transferred 
through the director network, from price movements based on information that is not transferred through the director network.

Table 8 presents the cumulative abnormal returns (CAR) around earnings announcements of held connected stocks to isolate the returns gained from the information managers extract from directors. The earnings announcement CAR of held connected stocks is compared to the earnings announcement CAR of unheld connected stocks and unconnected stocks using long/short portfolios. The earnings announcement CAR of each stock within each portfolio is weighted using the equal-weighted, percent-weighted and dollar-weighted methodologies. To calculate abnormal returns a window of seven trading days $[t=-1, t=5]$ around the scheduled quarterly earnings announcement is used. The date of the earnings announcement is obtained from the Compustat database. The abnormal return each day is computed by subtracting the return of a size specific portfolio from the return of the firm. To calculate CAR, the abnormal returns over the seven days are summed.

\section{(Insert Table 8 about Here)}

Table 8 shows funds earn higher returns in connected stocks in the days surrounding earnings announcements. The CAR of the held connected portfolio is economically and statistically significant under all three specifications, ranging from 1.30 percent per quarter to 1.57 percent per announcement. In all three specifications, the held connected portfolio outperforms the unheld connected portfolio. The difference between the two portfolios ranges from 0.78 percent to 1.55 percent per quarter and is statistically significant in all three specifications ( $t=2.52$ to $t=3.81$ ). Similarly, the held connected portfolio outperforms the unconnected portfolio under all specifications. The difference between the 
two portfolios ranges from 0.84 percent to 1.17 percent per quarter and is statistically significant under all three specifications ( $t=3.08$ to $t=3.28)$.

Furthermore, the earnings announcement CAR of the held connected portfolio exceeds the returns of the two alternate benchmarks. In all three specifications the CAR of the held connected portfolio exceeds the CAR of the portfolio composed of connected stocks held by unconnected funds, ranging from 0.50 percent to 0.84 percent per announcement ( $t=2.49$ to $t=3.41$ ). Similarly, the CAR of the connected portfolio exceeds the CAR of the portfolio composed of connected stocks, before and after the connection is formed, in all three specifications, ranging from 0.67 percent to 2.06 percent per announcement ( $t=3.15$ to $t=4.26$ ). These results demonstrate that the higher earnings announcement CAR in the connected portfolio is not a reflection of the connected stocks, as a whole, having higher earnings announcement CARs. Instead, connected funds hold the connected stocks that produce the largest CAR around earnings announcements.

\section{Earnings Announcement Surprises and Director Connections}

If managers extract earnings information from directors, managers will buy connected stocks prior to positive earnings announcement surprises, and sell connected stocks prior to negative earnings announcement surprises. Focusing on earnings surprises as opposed to returns, allows us to further isolate the information that managers can extract from other factors that can affect stock returns. An earnings announcement surprise is defined as the difference between a stock's actual quarterly earnings per share (EPS) value and the mean quarterly EPS analyst forecast as reported by the IBES database. Consistent with $\mathrm{Yu}$ (2008), if the actual EPS value is less than the forecast EPS value, the surprise is 
defined as negative. If the actual EPS value is more than $\$ 0.04$ greater than the forecast EPS value, the surprise is defined as positive. If managers are able to extract information from directors about the future earnings of the connected firm, and act on this information, I hypothesize that fund managers will hold connected stocks prior to positive earnings surprises and avoid holding connected stocks prior to negative earnings surprises. Furthermore, I hypothesize that connected stock purchase will precede positive earnings surprises while connected stock sales will precede negative earnings announcements.

Tables $9 \mathrm{a}$ and $9 \mathrm{~b}$ present the results of pooled OLS regressions which measure the impact of connected stock portfolio decisions on the subsequent earnings announcement surprises of those stocks at the stock-quarter level. The dependent variable is a dummy variable indicating if the earnings announcement is positive (Table 9a) and a dummy variable indicating if the earnings announcement is negative (Table 9b). Thus the coefficient on the independent variables indicates the impact each variable has on the probability the stock experiences a positive or negative earnings announcement surprise. The independent variables of interest are dummy variables indicating if a connected stock is held or not held (column 1), dummy variables indicating if a connected stock experienced net purchasing or net selling activity (column 2), and dummy variables indicating if a connected stock is purchased for the first time or if its position is totally sold (column 3). Control variables include each stock's institutional holding, market-to-book ratio quintile, asset growth and log market capitalization. Quarter fixed effects are included and T-Stats are reported below the coefficient estimates.

\section{(Insert Table 9a about Here)}


The first column of Table 9a examines the impact a connected stock holdings on the probability the subsequent earnings announcement surprises for the stock is positive. The results show that if a connected stock is held by a connected fund, the probability of a positive earnings surprise increases by 4.8 percent $(t=4.56)$. A connected stock being unheld increases the probability of a positive earnings surprise by 1.6 percent $(t=2.05)$. These findings are consistent with the results of the earnings announcement CAR analysis. Held connected stocks outperform, but unheld connected stocks do not underperform, indicating that connected stocks as a whole are more likely to experience positive earnings surprises compared to unconnected stocks. If managers extract earnings information about connected stocks from directors, we would expect held connected stocks to outperform unheld connected stocks. In support of this hypothesis, the 3.2 percent difference between the connected held and connected not held variables is statistically significant at the 1 percent level.

The second column of Table 9a shows the impact of connected stock trades on the probability the subsequent earnings announcement surprise for the stock is positive. If a connected stock experiences net purchases by connected funds prior to the earnings announcement, the probability the earnings announcement is positive increases by 5.7 percent $(t=3.64)$. If a connected stock experiences net sales by connected funds prior to the earnings announcement, the probability the earnings announcement is positive increases by 1.9 percent ( $t=1.16)$. Finally, if a connected stock is held but experiences no net trading activity, the probability of a positive earnings announcement increases by 5.4 percent $(t=2.30)$. If managers extract information from directors, we would expect connected stock purchases to be more likely to precede positive earnings surprises than connected stock sales. Consistent with this hypothesis, the 3.8 percent difference between the connected purchase and 
connected sale variables is statistically significant at the 10 percent level. Looking at the connected not traded variable, we see that this difference is driven not by connected purchases outperforming, but by connected sales underperforming. The fact that the connected sales coefficient is positive is a reflection of the fact that connected stocks as a whole are more likely to experience positive earnings announcement surprises over the sample period.

In the third column of Table 9a, I distinguish between stocks that are purchased for the first time (Connected Initial Purchase), and stocks that are purchased on top of existing holdings (Connected Partial Purchase); and distinguish between sales that only partially sell the position (Connected Partial Sale), and stock sales that completely sell out a position (Connected Total Sale). I do this to gauge the conviction of the managers trading decisions. Completely selling ones stake in a stock is a stronger signal than only selling part of that stake. Connected stocks that are initial purchased are 5.2 percent more likely to experience a positive earnings surprise $(\mathrm{t}=1.40)$, while connected stocks that are partially purchased are 5.8 percent more likely to experience a positive earnings surprise $(t=3.38)$. Conversely, connected stocks that are completely sold are 3.9 percent less likely to experience a positive earnings surprise $(\mathrm{t}=-\mathbf{1 . 0 7})$, while connected stocks that are partially sold are 3.2 percent more likely to experience a positive earnings surprise $(t=1.82)$. The results show there is no statistical difference between initial and partial purchases. However, the results indicate that stocks that experience total sales are less likely to experience positive earnings surprises than all connected purchases (5 percent statistical significance level), initial connected purchases (10 percent significance), and partial connected sales (10 percent significance).

(Insert Table 9b about Here) 
Table $9 \mathrm{~b}$ repeats the analysis of Table 9a, with the exception that the dependent variable is now a dummy variable indicating if a stock experiences a negative earnings announcement surprise. The first column of Table $9 \mathrm{~b}$ shows the impact a connected stock being held or not held by a connected fund has on the probability the subsequent earnings announcement surprises for the stock is negative. A connected stock being held decreases the probability of a negative earnings surprise by 1.6 percent $(\mathrm{t}=-$ 1.32), while a connected stock being unheld increases the probability of a negative earnings surprise by 1.4 percent ( $\mathrm{t}=1.67)$. If managers extract earnings information about connected stocks, we would expect held connected stocks to be less likely to experience negative earnings surprises compared to unheld connected stocks. In support of this hypothesis, the 3.0 percent difference between the connected held and connected not held variables is statistically significant at the 5 percent level.

The second column of Table $9 \mathrm{~b}$ shows the impact of connected stock trades on the probability the subsequent earnings announcement surprise for the stock is negative. If a connected stock experiences net purchases by connected funds prior to the earnings announcement, the probability the earnings announcement is negative decreases by 2.7 percent $(t=-1.55)$. If a connected stock experiences net sales by connected funds prior to the earnings announcement, the change in the probability the earnings announcement is negative is indistinguishable from zero $(t=-0.01)$. Finally, if a connected stock is held but experiences no net trading activity, the probability of a negative earnings announcement increases by 1.2 percent $(t=0.49)$. The 2.7 percent difference between the coefficients for the stock purchase and stock sales variable is not statistically significant.

Lastly, the third column of Table 9b identifies connected stocks purchased for the first time, and connected stocks sales that complete sell out a position. Connected stocks that are initial purchased are 
3.8 percent less likely to experience a negative earnings surprise $(t=-0.93)$, while connected stocks that are partially purchased are 2.5 percent less likely to experience a negative earnings surprise ( $\mathrm{t}=-\mathbf{1 . 2 9}$ ). Conversely, connected stocks that are completely sold are 8.5 percent more likely to experience a negative earnings surprise $(\mathrm{t}=2.11)$, while connected stocks that are partially sold are 2.0 percent less likely to experience a negative earnings surprise $(t=-1.03)$. These results again show there is no statistical difference between initial and partial purchases. However, the results indicate that stocks that experience total sales are more likely to experience negative earnings surprises than all connected purchases (1 percent statistical significance level), initial connected purchases (5 percent significance), and partial connected sales (5 percent significance). Overall, the results of Tables 9a and 9b lend support to the hypothesis that mutual funds use the director network to facilitate the acquisition of information on connected firms.

Cremers, Driessen, Maenhout and Weinbaum (2009) find that the impact of directors on mutual fund performance extends beyond their fiduciary fee negotiation responsibilities. They show that director incentives explain the performance gap, but do not explicitly identify how a well-aligned director improves fund performance. My findings identify one possible mechanism; well-aligned directors facilitate the transfer of information to the fund, leading to abnormal returns in connected holdings.

\section{Results: The Director Network and AUM Fund Flows}

Director and manager incentives spur an exchange of information within the director network. A similar set of incentives exists within the director network with respect to investable assets. A mutual 
fund's profitability is a function of its assets under management (AUM). Publicly traded firms guide the investment of large pools of money through $401(\mathrm{~K})$ and pension plans. Like information flow, I hypothesize that mutual funds use the director network to facilitate asset flows from the connected firm to the fund. This section tests the hypothesis that fund-firm relationships created by the director network lead to increased fund flows for connected funds.

Panel A of Table 10 uses pooled OLS regressions to test if the director network impacts annual AUM fund flows. Fund Flow is defined as the changes in a fund's Total Net Assets (TNA) after adjusting for the returns of the fund. The CRSP Mutual Fund database provides monthly TNA and return data for mutual funds. For details on the methodology used to calculate Fund Flows see Appendix B. To be included in the sample for a given year funds must have TNA and return data for all twelve months of the year, and have TNA greater than $\$ 10$ million. Funds which were involved in a fund merger over the life of the sample (either acquirer or target) are excluded. The independent variable of interest is the number of firms each fund is connected to. A set of controls is included in order to isolate the effect of the connection. These controls include a variable for the fund's size, past returns and style. The fund style controls are calculated by taking the weighted average of the DGTW characteristics (size, value, momentum) of the stocks held by each fund, and grouping funds into quintiles based on the fund average of each characteristic. This creates 125 unique fund styles. Year fixed-effects are included and standard errors are clustered at the fund level. The dependent variable is the fund's annual fund flow (column 1), a dummy variable indicating the fund is in the highest quintile of fund flow for the year (column 2), and a dummy variable indicating the fund is in the lowest quintile of fund flow for the year (column 3). If funds use director connections to improve fund flows, more connected funds should have 
higher fund inflows, be more likely to experience fund flows in the highest quintile for the year, and be less likely to experience fund flows in the lowest quintile for the year.

\section{(Insert Table 10 about Here)}

The results of Table 10 show that director connections have a statistically and economically significant impact on annual fund flows. For each director connection, a fund increases its annual flow by 1.53 percentage points $(t=5.31)$. With respect to the probability of the fund experiencing inflows in the highest and lowest quintiles of the mutual fund universe, the effect of director connections is ambiguous. For each connection, the probability the fund is in the highest quintile increases by 0.64 percentage points $(t=4.59)$. Contrary to the hypothesis that connections help AUM inflow, I find each connection increases the probability the fund is in the lowest quintile by 0.03 percentage points $(t=0.18)$.

Panel B of Table 10 expands the fund flow analysis by distinguishing between connections that the fund holds, and connections that the fund does not hold. Cohen and Schmidt (2009) find evidence of a reciprocatory relationship between funds and firms. They show that funds overweight holdings in firms for whom they are the $401(\mathrm{~K})$ trustee, and these overweight holdings are not linked to any information effect as measured by abnormal returns. If a similar reciprocatory relationship occurs in the director network, I expect the fund flow benefits associated with held connections to be greater than the fund flow benefits derived from unreciprocated unheld connections. I find each held connection increases annual fund flow by 4.57 percentage points $(t=4.19)$, increases the probability the fund is in the top fund flow quintile by 1.22 percentage points $(t=2.52)$, and decreases the probability the fund is in 
the lowest fund flow quintile by 1.551 percentage points $(t=-3.80)$. The effect of unheld connections on fund flow is less clear. Each connection the fund does not hold increases annual fund flow by 1.01 percentage points ( $t=3.47$ ), increases the probability the fund is in the top fund flow quintile by 0.56 percentage points $(t=3.66)$, but also increases the probability the fund is in the lowest fund flow quintile by 0.24 percentage points ( $t=1.54)$.

My results extend the understanding of how mutual funds secure AUM inflows. Cohen and Schmidt (2009) explore the impact of $401(K)$ relationships on the fund, finding mutual funds use reciprocating relationships with publicly traded firms to secure $401(\mathrm{~K})$ trusteeships, which in turn insures constant fund flows into the fund. While I do not explicitly identify $401(\mathrm{~K})$ or Pension trusteeships as the inflow increasing mechanism, my result can be interpreted as implicit evidence that the director network is involved in the $401(\mathrm{~K})$ and Pension trusteeship process.

\section{Vl. Conclusion}

This paper investigates the impact of the director network on the portfolio choices, investment returns and fund flows of mutual funds. I find funds hold larger stakes in connected stocks, these holdings earn superior CAR around earnings announcement, and the buying and selling of these holdings coincide with positive and negative earnings announcement surprises. These findings lend support to the hypothesis that the holdings are information driven. In addition to information flow, I find the director network facilitates asset inflows into the fund. Connected funds experience higher fund inflows than unconnected funds, and the effect is especially pronounced when the fund holds the connected firm. 
Overall, the results of this paper suggest that the director network plays an integral role in the exchange of information and favors between mutual funds and publicly traded firms. Due to data limitations, this paper conservatively measures the director network. I expect the true scope of the director network to be larger than what is presented. 


\section{$\underline{\text { References }}$}

Anderson, R., Mansi, S., Reeb, D., Board Characteristics, Accounting Report Integrity, and the Cost of Debt, Journal of Accounting and Economics, September 2004.

Carhart, M., 1997, On Persistence in Mutual Fund Performance, Journal of Finance 52, 57-82.

Chen, Q., Goldstein, I., Jiang, W., 2008, Director Ownership in the U.S. Mutual Fund Industry, Journal of Finance 63, 2629-77.

Cohen, L., 2009, Loyalty Based Portfolio Choice, Review of Financial Studies 22, 1213-1245.

Cohen, L., Frazzini, A., Malloy C., 2008, The Small World of Investing: Board Connections and Mutual Fund Returns, Journal of Political Economy, 116, 951-979.

Cohen, L., Schmidt, B., 2009, Attracting Flows by Attracting Big Clients. Journal of Finance 64, 2125-2151.

Cohen, R., Polk, C., Silli, B., 2010, Best Ideas, Working paper, London School of Economics.

Cremers K., Driessen J., Maenhout P., Weinbaum D., 2009, Does Skin in the Game Matter? Director Incentives and Governance in the Mutual Fund Industry, Journal of Financial and Quantitative Analysis, Vol. 44, No. 6, 1345-1373.

Daniel, K., Grinblatt, M., Titman, S., Wermers, R.. 1997, Measuring Mutual Fund Performance with Characteristic-Based Benchmarks, Journal of Finance 52,394-415.

Del Guercio, D., Dann, L., Partch, M., 2003, Governance and boards of directors in closed-end investment companies, Journal of Financial Economics 69, 111-152.

Duan Y., Hotchkiss, E., Jiao, Y., 2011, Business Ties and Information Advantage: Evidence from Mutual Fund Trading, University of Alberta, Working Paper.

Engelberg, J., Sankaraguruswamy, S., 2007, How to Gather Data Using a Web Crawler: An Application Using SAS to Search Edgar, University of North Carolina, Working Paper.

Fama, E., French, K., 1993, Common Risk Factors in the Returns on Stocks and Bonds, Journal Financial Economics 33, 3-56.

Ferris S.P., Yan X.(S.), 2007, Do Independent Directors and Chairmen Matter? The Role of Boards of Directors in Mutual Fund Governance, Journal of Corporate Finance, 13 (2-3), 392-420.

Huberman, G., 2001, Familiarity Breeds Investment, Rev. Financial Studies, 14 (Fall): 659-80.

Hong, H., Kubik, J., Stein, J. , 2005, "Thy Neighbor's Portfolio: Word-of-Mouth Effects in the Holdings and Trades of Money Managers," Journal of Finance 60, 2801-2824. 
Khorana, A., Tufano, P., Wedge, L, 2007, Board Structure, Mergers, and Shareholder Wealth: A Study of the Mutual Fund Industry, Journal of Financial Economics, 85(2), 571-598.

Kuhnen, C., 2009, Business Networks, Corporate Governance, and Contracting in the Mutual fund Industry, Journal of Finance 64, 2185-2220.

Tufano, P., and Sevick, M., 1997, Board Structure and Fee-Setting in the U.S. Mutual Fund Industry, Journal of Financial Economics 46, 321-355.

Wermers, R., 2004, Is money really "smart"? New Evidence on the Relation between Mutual Fund Flows, Manager Behavior, and Performance Persistence, Working paper, University of Maryland.

Yu, F., 2008, Analyst Coverage and Earnings Management, Journal of Financial Economics 88, 245-271. 


\section{Appendix A: Director Network Data Collection}

Describing the director employment network was a multi-step process. First, the names of the directors of mutual funds had to be collected. Next, the mutual funds where the director worked and when they worked there had to be identified. Lastly, the public companies the directors worked at and when they worked there had to be identified. A fund-firm connection was defined as when an individual was the director of a mutual fund and employee of a fund company in the same year.

The first step in describing the director employment network was to identify the names of everyone who was on the board of directors of any mutual fund during the period 2000 to 2008 . This information was obtained from Standard \& Poor's Capital IQ database (Capital IQ). For each person listed in the database, Capital IQ also lists any affiliations the person has with publicly traded companies. This information is used to crosscheck the validity of each place of employment I identified.

The Capital IQ database has two shortcomings. It does not accurately identify the fund company - mutual fund relationship. This leads to an incomplete mapping of the director employment network. Secondly, it does not provide the timeframe of each director affiliation. The first shortcoming stems from the structuring of mutual funds. In the mutual fund industry the highest level of organization is the fund family. An example of a mutual fund family would be Vanguard or Fidelity. The next level of organization is known as the fund company. The fund company is the relevant unit for SEC filings, and is identified by a specific Central Index Key (CIK) number. A fund family can be comprised of one or many fund companies, there is no industry standard. Each fund company has one board of directors. Thus, I 
identify directors at the fund company level. In turn, each fund company is comprised of one to many mutual funds. All holdings data is at the mutual fund level. When studying the effect director connections have on mutual funds it is necessary to analyze the data at a consistent level of organization (fund family, fund company or mutual fund). Capital IQ fails in this respect, as it does not provide mutual fund affiliations in a consistent manner.

The Capital IQ database also fails to provide the exact dates that each director was affiliated with each mutual fund and public company. Suppose Capital IQ lists John Smith as being a director for Vanguard and an employee of General Electric. Without the exact dates of each affiliation it is unclear if a director connection exists. For example, suppose John Smith had been a director at Vanguard from 2000 to 2003, and worked at General Electric from 2005 to 2008. In this case no director connection would exist. Furthermore, in studying the effect of director connections on mutual funds, I only considered current director connections. Suppose Lou Jones was a director at Fidelity from 2004 to 2008, and worked at IBM from 2002 to 2006 . By my definition, a director connection would only exist in the years 2004 to 2006, when Lou was simultaneously a director at Fidelity and an employee of IBM. Since Capital IQ does not provide the exact dates of each affiliation, using only this database it is impossible to identify which years the connection exists.

To overcome the shortcomings of the Capital IQ database, I use a methodology similar to the procedure employed by Kuhnen (2009). First I use the Capital IQ database to identify the names of all persons listed as directors of mutual funds. Fund companies are required to list their board of directors in Form N-CSR (the N-30D form prior to 2003), and public companies are required to list their Directors, Executive Officers and Corporate Governance in Form 10-K. Thus, by searching all Form N-CSR [and N- 
30D] fund company filings and Form 10-K public company filings from 2000 to 2008 in the SEC Edgar Database for the names identified in the Capital IQ database, I was able to map the board of directors for each fund company for each year, and the public companies these directors where affiliated with each year. By cross-referencing the identified director information (director name and year) from Form N-CSR and Form 10-K I am able to identify director connections for each year from 2000 to 2008.

Each year there are approximately 4,000 N-CSR forms filed and 10,000 10-K forms filed with the SEC. Because of the massive volume of information filed by mutual funds and public companies it is necessary to automate the search for director names. To automate this process I used a modified version of the web crawler algorithm developed by Engelberg and Sankaraguruswamy (2007) which allows researchers to "crawl" the SEC Edgar Database, accessing information disclosed by firms. Successfully running the web crawler algorithm requires the information I want to search within the form and the internet locations of the form, in this case the N-CSR, N-30D and 10-K forms. The location of every SEC form is documented in master.idx files located at: ftp://www.sec.gov/edgar/full-index/. For each form, this database provides a web location, date, form type, company name and company CIK number. Filtering the entire database by form type allowed me to isolate the locations of Form N-CSR, N-30D and 10-K from over 600 SEC form types.

Once the locations of the forms were established, I used the algorithm to "crawl" each form for the names identified in the Capital IQ Database. The output of this process was a database which stated the date, form type, company name, company CIK and director name. By cross-referencing the names and years in the resulting Form N-CSR database with the Form 10-K database, I was able to identify director connections for each year from 2000 to 2008. Once the connections were identified, I cross- 
referenced each connection with the original Capital IQ database which lists the affiliated companies of each director. A connection is only kept if the public firm in the connection is also listed as an affiliated company in the Capital IQ database. This additional robustness measure eliminates approximately half of the connections in the sample. However, it insures that I am not including spurious connections where John Smith who works at Vanguard and IBM, is not confused with a different John Smith who is an employee of GE.

The director employment information obtained from the Capital IQ database was supplemented using information from the Compustat Execucomp database. The Compustat Execucomp database provides the first, middle and last name of corporate executives, as well as the firm they work for and when they work there. These names were then used to search all Form N-CSR (and N-30D) fund company filings using the Engelberg Sankaraguruswamy (2007) algorithm. By cross-referencing the two datasets I was able to identify addition director connections.

Lastly, I remove fund employees from the director connection database using two methods. Capital IQ maintains a dataset identifying fund employees. I cross-referenced the names in this dataset against names in my director's connection dataset, removing any names that appeared in both datasets. The second robustness measure focuses on the number of directors connecting a fund and firm in a given year. If three or more directors have the same fund-firm connection in a given year, I remove the directors from the sample under the assumption that the directors are employees of the fund. If the firm has a "Finance or Insurance" NAICS code, the cut off is two or more directors. This process is to remove instances where the fund is a subsidiary of a publicly traded firm, and thus all non-independent directors of the fund are also employees of the firm. 
The SEC mutual fund fillings are at the fund company level. As a result, the connections database connects publicly trading companies with fund companies. However, mutual fund holding data is recorded at the mutual fund level. Thus the next step of the data collection involved mapping fund companies to the mutual funds they oversee.

A fund company is required to list all of the mutual funds that they oversee in Form NSAR-B, line 007C. Unlike Form N-CSR, N-30D and 10-K, Form NSAR-B is uniformly structured. Thus, I did not need to individually search for each mutual fund's name. The fund company - mutual fund mapping algorithm searches Form NSAR-B, extracting any line beginning with "007C". It then uses "regular expression" coding techniques to isolate the mutual fund name from the line. The output of this algorithm (combined with a similar algorithm for a single mutual fund, fund companies that searches line "001A") is a database which contains all of the underlying mutual funds for each fund company each year. Merging this database with the director connection database creates a new database which contains director connections at the mutual fund level.

After identifying director connections at the mutual fund level, the next step in the data collection process was to connect the director connections database to the mutual fund holdings database. This is an essential step in studying how director connections affect the portfolio choice and investment performance. Mutual fund holdings data is contained in the Thompson/s12 Database. Because there is no shared identifier between the s12 database and the director connections database, the mutual fund names need to be matched between the two databases using fuzzy logic algorithms. Further complicating matters is the fact that the mutual fund names listed in the $\$ 12$ database are incomplete. To solve this problem the CRSP Mutual Fund database is used in the matching process. The 
CRSP Mutual Fund database lists more complete mutual fund names than the s12 database. The two databases share a common identifier via the MFLINKS file. Thus, I matched the mutual fund names in the CSRP Mutual Fund database with my director connections database, and then linked the mutual fund matches to names in the s12 database via the MFLINKS file.

The mutual fund names in each database are not always spelled exactly the same. As a result I cannot simply cross-reference the names using a tradition database merge. Over the nine years spanned by the sample there are 33,971 mutual fund entries in the CRSP database which need to be matched to the mutual fund names from the director connections database. The large size of the sample necessitates automating the process using a name matching algorithm. In addition to their web crawler algorithm, Engelberg and Sankaraguruswamy (2007) make available an effective name matching algorithm ${ }^{9}$ which outputs a score for each name match. This algorithm greatly reduced the amount of matching that needed to be done by hand. This process allowed me to match 32,596 of 33,971 entries (94.3 percent) in the CRSP database with my director connection database. After using MFLINKS to connect the CRSP database to the s12 database, I successfully identified matches for 4710 of 5087 funds in the s12 database. The reason for the smaller number of funds in the s12 database is because it includes only mutual funds, whereas the CRSP database includes funds and any underlying fund classes.

\footnotetext{
${ }^{9}$ SAS also has built-in "fuzzy" text matching algorithms. In practice I found the matching algorithm provided by Engelberg and Sankaraguruswamy (2007) to be much more effective than the SAS algorithms. I am greatly indebted to them for providing these algorithms which greatly improved my ability to gather the database used in this paper.
} 


\section{Appendix B: Holding Size Measurement Details}

\section{Holdings Size Measurements}

"Percent Held," is the proportion of connected and unconnected funds holding a given stock. If 10 Funds were connected to Stock B in the first quarter of 2005, and two of the funds held Stock B, the "Percent Held" statistic would equal $2 / 10$ or 0.20 .

"Portfolio Weight," is the portfolio weight of a stock within the fund's portfolio. If the fund has $\$ 1,000,000$ in total holdings and holds $\$ 10,000$ of stock $A$, stock $A$ would have a portfolio weight of 1 percent. Formally:

Portfolio Weight = Stock A Fund Portfolio Weight = (Dollar Holdings of Stock A by Fund B) $/$ (Total Dollar Holdings of Fund B) $P W_{a B}=\frac{H_{a B}}{\sum_{i} H_{i B}}$

Cohen, Polk and Silli (2010), propose two additional benchmark-adjusted measures to gauge a manager's view on mispricing. The first, "Market Tilt", compares the portfolio weights of a stock in a given mutual fund to the market capitalization weight of the stock. This would be the appropriate adjustment to use if managers are benchmarked against the total market. Thus if a stock has a 2 percent weight in the fund's portfolio, and a 0.5 percent market capitalization weight, it would have a market tilt of 1.5 percent. Formally:

Market Tilt $=$ Stock $A$ Portfolio Weight in Fund B - (Stock A CRSP Universe Weight) 


$$
M T_{a B}=P W_{a B}-\frac{V_{a}}{\sum_{i} V_{i}}
$$

Because not all managers are benchmarked against the market, Cohen, Silli and Polk (2010) argue that Market Tilt is not always the appropriate benchmark adjustment to use. Instead the ideal benchmark would be one relevant to the specific manager. They formulate a manager specific benchmark, "Portfolio Tilt." This measure is constructed as the market capitalization weighted portfolio of stocks contained in the manager's portfolio. Specifically, "suppose that a portfolio consisted of Stocks $A$ and $B$, each of which make up only a very tiny fraction of the stock market. Further, suppose that Stock A has twice the market capitalization of Stock B. Then, in this weighting scheme, Stock $A$ would have a benchmark weight of 66.67 percent, and Stock B a benchmark weight of 33.33 percent. If the portfolio held equal dollar amounts of Stock $A$ and Stock $B$, Stock $A$ would be viewed as being underweight by 16.67 percent, while Stock B as being overweight by 16.67 percent." Formally Portfolio Tilt is defined as:

Portfolio Tilt $=$ Stock $A$ Fund Portfolio Weight - (Stock A Market Capitalization /Aggregate Fund Market Capitalization)

$M T_{a B}=P W_{a B}-\frac{V_{a}}{\sum_{i} V_{i B}}$

\section{Portfolio Return Weighting Methods}

"Equal-Weighted" - Each stock is given equal weight. In the equal-weighted portfolio, if multiple funds hold a stock, I count that stock only once. A stock held by two funds receives the same weight as a stock held by one fund. 
Stock A Equal Weight $=1 /($ Number of Stocks in Portfolio B)

$e \omega_{A, B}=\frac{1}{\sum_{i} 1}$

"Percent-Weighted" - Gives larger weight to stocks with larger portfolio weights. Fund size is not a factor.

Stock A Percent Weight $=($ Portfolio Weight of Stock A in Fund $B) /($ Aggregate of all Stocks Portfolio Weights)

$p \omega_{A, B}=\frac{P W_{A B}}{\sum_{i} \sum_{j} P W_{i j}}$

"Dollar-Weighted" - Gives larger weight to stocks with larger dollar holdings. Thus the holdings of larger funds receive more weight than the holdings of smaller funds.

Stock A Dollar Weight = (Holdings of Stock A in Fund B)/ (Aggregate of all Stocks Holdings).

$$
d \omega_{A, B}=\frac{H_{A B}}{\sum_{i} \sum_{j} H_{i j}}
$$

\section{Fund Flow Measures}

"Fund Flow" is defined as the changes in a fund's Total Net Assets (TNA) after adjusting for the returns of the fund. The CRSP Mutual Fund database provides monthly TNA and return data for mutual funds. Formally Monthly Flow is defined as: 
Monthly Flow $=$ Fund A's Total Net Assets in Month $t-(1-$ Retutrn of Fund A in Month $t) *($ Fund A's Total Net Assets in Month t-1.)

$M F_{A t}=T N A_{A t}-\left(1+R_{A t}\right) *\left(T N A_{a t-1}\right)$

Annually Flow is defined as the aggregate of all the monthly flows for a given year divided by the total net assets in the previous year.

$A F_{A y}=\frac{\sum_{t=1}^{12} M F_{A t}}{T N A_{y-1}}$ 
Table 1: Sample Overview

Summary Statistics: Director Connections,2000-2008

\begin{tabular}{|c|c|c|c|c|c|c|}
\hline Panel A: Aggregate Fund Data & Total Unique & Mean & Median & Min & Max & $\mathrm{N}$ \\
\hline Connections per Year & 4165 & 1360 & 1433 & 772 & 1630 & 9 \\
\hline Fund Companies per Year & 1132 & 792 & 815 & 639 & 893 & 9 \\
\hline Mutual Funds per Year & 3920 & 2509 & 2648 & 1824 & 2820 & 9 \\
\hline Held Connections per Quarter & 865 & 212 & 231 & 42 & 279 & 36 \\
\hline Panel B: Fund Level Data & & Mean & Median & Min & Max & $\mathrm{N}$ \\
\hline Directors per Fund Company per Year & & 5.82 & 5 & 1 & 27 & 7118 \\
\hline Connections per Fund Company per Year & & 1.72 & 1 & 0 & 11 & 7118 \\
\hline Connected Firms Held per Mutual Fund per Quarter & & 0.14 & 0 & 0 & 9 & 84739 \\
\hline
\end{tabular}

Note - Table 1 reports summary statistics for the sample. Panel A presents data on the size of the sample, specifically the number of fund companies, funds, connections and held connections. Unique observations refer to the number of unique observations over the 9 year sample period. Results are present at the quarter or year level as specified. Panel B presents the number directors and connections for each fund company averaged across all fund companies over all years or quarters as specified. The fourth row of Panel B presents data at the mutual fund level. Most Fund Companies are comprised of many mutual funds, with an average of approximately three. 
Table 2: Connected Firm Characteristics

Summary Statistics: Director Connections, Firm Data, 2000-2008

\begin{tabular}{|c|c|c|c|c|c|}
\hline Panel A: Firm-Connections & Mean & Median & Min & Max & $\mathrm{N}$ \\
\hline \multicolumn{6}{|c|}{ Proportion of CRSP Stock Universe Connected } \\
\hline of Stocks & 0.0393 & 0.0439 & 0.0190 & 0.0499 & 9 \\
\hline of Total Market Value & 0.1486 & 0.1338 & 0.0897 & 0.2302 & 9 \\
\hline \multicolumn{6}{|c|}{ Proportion of CRSP Stock Universe that is a Held Connection } \\
\hline of Stocks & 0.0109 & 0.0122 & 0.0032 & 0.0135 & 36 \\
\hline of Total Market Value & 0.0782 & 0.0726 & 0.0417 & 0.1514 & 36 \\
\hline Panel B: Connected Firm Size (\$Billions) & Mean & Median & Min & Max & $\mathrm{N}$ \\
\hline Connected Firm Size & 9.06 & 1.62 & 0.00 & 366.23 & 582 \\
\hline Held Connected Firm Size & 16.36 & 3.74 & 0.08 & 366.23 & 237 \\
\hline Average Firm Size in CRSP & 1.94 & 0.25 & 0.00 & 366.23 & 10089 \\
\hline
\end{tabular}

Note - Table 2 presents summary statistics on the scope of connected firms, the size of connected firms and the funds that hold connected firms. Panel A shows the proportion of CRSP stocks that are connected to funds, and the proportion of CRSP stocks that are held by at least one connected fund. The data is presented as the proportion of stocks and as the total market value of all stocks. Panel B shows the market capitalization of connected firms, held connected firms and stocks within the mutual fund sample, expressed in billions. For each stock, the reported size is the average market cap in $\$$ Billions of the firm over the nine year sample periord. 
Table 3: Connected Holdings Versus Unconnected Holdings

Connected Funds versus Unconnected Funds

\begin{tabular}{lcccc}
\hline & $\mathrm{N}$ & Connected & Unconnected & Difference \\
Percent Held & 9867 & 0.055 & 0.050 & 0.0055 \\
& & & & 4.28 \\
Portfolio Weight & 9867 & 0.00046 & 0.00042 & 0.00004 \\
& & & & 2.41
\end{tabular}

Note - Table 3 compares the average holdings of all funds connected to a stock to the average holdings of all funds not connected to that stock for each connected stock. The level of observation is the Firm-Quarter. The Percent Held measure is the proportion of funds that hold the connected stock, the Portfolio Weight measure is the weight of a stock within a fund's portfolio. T-Stats are reported below the coefficient estimates. 
Table 4: OLS Regression: Conditional Holdings in Connected vs. Unconnected Stocks

\begin{tabular}{lccccc}
\hline \hline Dependent Variable & $\mathrm{N}$ & Connected & Controls & Fixed Effect & $\mathrm{R}^{2}$ \\
\hline \hline Portfolio Weight & 10304794 & $\begin{array}{c}0.00055 \\
7.00\end{array}$ & Yes & Quarter, Fund & 0.559 \\
& & & & \\
Market Tilt & 10304794 & 0.00048 & Yes & Quarter, Fund & 0.537 \\
& & 6.30 & & & \\
Portfolio Tilt & 10304794 & 0.00034 & Yes & Fund & 0.042 \\
& & 2.21 & & & \\
\hline
\end{tabular}

Note - Table 4 reports pooled OLS quarterly regressions of mutual fund portfolio weights in connected and unconnected stocks. The sample period is 2000 to 2008, and the units of observation are fund-stock-quarter. Three different dependent variable are used to measure the weight of a fund's holding. Portfolio Weight ([Stock's Holdings]/[Fund's Total Holdings]), Market Tilt (Stock's Fund Portfolio Weight - Stock's Market Capitalization Weight) and Portfolio Tilt (Stock's Fund Portfolio Weight - (Stock's Market Cap/Aggregate Fund Market Capitalization). The independent variable of interest is a dummy variable identifying a stock as connected. The control variables included are \%STYLE, the percentage of the fund's total net assets invested in the style corresponding to the stock being considered (per Cohen et al. [2008]), and quintiles of market value of equity, book to market, and past 12-month return (As provided by DGTW). Quarter and Fund fixed effects a re included. The Portfolio Tilt measure does not include quartly fixed effects as the construction of the statistic aleady accounts for quartly varaitions. T-Stats are reported below the coefficient estimates. 
Table 5: Director Connection Formation Holdings Timeline

\begin{tabular}{lcccc}
\hline \hline Panel A: Connection Formation (+/-2Years) & & & \\
\hline & $\mathrm{N}$ & Pre Formation & Post Formation & Difference \\
Percent Held & 3887 & 0.08113 & 0.00804 & 2.57 \\
& & & 0.08917 & 0.00014 \\
Portfolio Weight & 3887 & 0.00067 & 2.92 \\
& & & 0.00082 & Difference \\
\hline Panel B: Connection Termination (+/- 2 Years) & $\mathrm{N}$ & & -0.00686 \\
Percent Held & 3124 & Pre Termination & Post Termination & -1.81 \\
& & 0.09903 & 0.09217 & -0.00017 \\
Portfolio Weight & 3124 & & 0.00077 & -2.78 \\
\hline
\end{tabular}

Note - Table 5 analyzes the relationship between the timeline of the connection and the connected funds level of holdings of the connected firm for each fund-firm connection using paired T-Tests. Panel A compares the level of holdings of each fund-firm connection in the 8 quarters prior to the formation of the connection and in the 8 quarters following the formation of the connection. Panel B compares the level of holdings of each fund-firm connection in the 8 quarters prior to the termination of the connection and in the 8 quarters following the termination of the connection. The year of the connection formation and termination are excluded from the analysis. Holdings are measured in two different ways. The percent held measure is the proportion of funds that hold the connected stock. The portfolio weight measure is the average portfolio weight of the firm in each fund, including funds that do not hold the firm. TStats are reported below the coefficient estimates. 
Table 6: Connected Returns: 2000-2008

\begin{tabular}{|c|c|c|c|c|c|c|}
\hline & $\mathrm{N}$ & $\begin{array}{l}\text { Connected Funds } \\
\text { Held Stocks }\end{array}$ & $\begin{array}{l}\text { Connected Funds } \\
\text { Unheld Stocks } \\
\text { Long/Short }\end{array}$ & $\begin{array}{l}\text { Unconnected Funds } \\
\text { All Stocks } \\
\text { Long/Short }\end{array}$ & $\begin{array}{c}\text { Unconnected Funds } \\
\text { Connected Stocks } \\
\text { Long/Short }\end{array}$ & $\begin{array}{c}\text { Connected Funds } \\
\text { Before/After Connection } \\
\text { Long/Short }\end{array}$ \\
\hline \multicolumn{7}{|c|}{ Panel A: FF 4-Factor Model } \\
\hline \multirow[t]{2}{*}{ Equal-Weighted } & 108 & 0.0024 & -0.0016 & -0.0012 & -0.0012 & -0.0010 \\
\hline & & 1.24 & -0.86 & -0.64 & -0.94 & -0.54 \\
\hline \multirow[t]{2}{*}{ Dollar-Weighted } & 108 & 0.0015 & 0.0008 & 0.0015 & 0.0014 & 0.0021 \\
\hline & & 0.47 & 0.22 & 0.48 & 0.69 & 0.53 \\
\hline \multirow[t]{2}{*}{ Percent-Weighted } & 108 & 0.0007 & -0.0006 & 0.0000 & 0.0011 & 0.0021 \\
\hline & & 0.31 & -0.27 & 0 & 0.57 & 0.70 \\
\hline \multicolumn{7}{|l|}{ Panel B: DGTW } \\
\hline \multirow[t]{2}{*}{ Equal-Weighted } & 108 & -0.001 & -0.002 & 0.000 & -0.002 & -0.002 \\
\hline & & -0.18 & -0.83 & 0.00 & -1.22 & -1.07 \\
\hline \multirow[t]{2}{*}{ Dollar-Weighted } & 108 & -0.004 & -0.003 & 0.000 & -0.001 & 0.000 \\
\hline & & -0.72 & -0.67 & -0.10 & -0.31 & -0.11 \\
\hline \multirow[t]{2}{*}{ Percent-Weighted } & 108 & -0.002 & -0.002 & 0.001 & 0.001 & 0.000 \\
\hline & & -0.58 & -0.61 & 0.30 & 0.64 & 0.04 \\
\hline
\end{tabular}

Note - Table 6 reports calendar time portfolio returns. At the beginning of every calendar quarter, stocks in each mutual fund portfolio are assigned to one of five portfolios (connected held, connected not held, unconnected, unconnected funds-connected firms and connected funds-before/after connection). Monthly returns are computed for the holdings of each portfolio between quarters based on the assumption that funds did not change their holdings between quarters. Portfolios are rebalanced every calendar quarter. Where indicated stocks are equally weighted, weighted by the fund's dollar holdings (dollar holdings/total portfolio dollar holdings) or weighted by their weight in their fund's portfolio (portfolio percent holding/aggregate percent holding). Returns are risk-adjusted using four-factor alpha adjusted returns and DGTW characteristic adjusted returns. T-Stats are reported below the coefficient estimates. 
Table 7: Connected Returns: Following Purchases and Sales 2000-2008

\begin{tabular}{|c|c|c|c|c|c|}
\hline Panel A: Purchases & $\mathrm{N}$ & $\operatorname{RET}(t+1)$ & $\operatorname{RET}(t+1, t+2)$ & $\operatorname{RET}(t+1, t+3)$ & $\operatorname{RET}(t+1, t+4)$ \\
\hline \multirow[t]{2}{*}{ Equal Weighted } & 35 & 0.0005 & 0.0046 & 0.0043 & 0.0039 \\
\hline & & 0.11 & 1.09 & 1.20 & 1.28 \\
\hline \multirow[t]{2}{*}{ Dollar Weighted } & 35 & -0.0008 & 0.0040 & 0.0052 & 0.0040 \\
\hline & & -0.16 & 0.86 & 1.23 & 1.08 \\
\hline \multirow[t]{2}{*}{ Percent Weighted } & 35 & -0.0003 & 0.0046 & 0.0063 & 0.0052 \\
\hline & & -0.05 & 0.88 & 1.33 & 1.37 \\
\hline Panel B: Sales & $\mathrm{N}$ & $\operatorname{RET}(t, t+1)$ & $\operatorname{RET}(t, t+2)$ & $\operatorname{RET}(t, t+3)$ & $\operatorname{RET}(t, t+4)$ \\
\hline \multirow[t]{2}{*}{ Equal Weighted } & 35 & 0.0032 & 0.0028 & 0.0034 & 0.0039 \\
\hline & & 0.64 & 0.64 & 0.90 & 1.23 \\
\hline \multirow[t]{2}{*}{ Dollar Weighted } & 35 & 0.0007 & 0.0009 & 0.0041 & 0.0051 \\
\hline & & 0.10 & 0.17 & 1.01 & 1.45 \\
\hline \multirow[t]{2}{*}{ Percent Weighted } & 35 & 0.0063 & 0.0042 & 0.0038 & 0.0040 \\
\hline & & 0.95 & 0.67 & 0.79 & 0.98 \\
\hline Panel C: Long/Short & $\mathrm{N}$ & $\operatorname{RET}(t, t+1)$ & $\operatorname{RET}(t, t+2)$ & $\operatorname{RET}(t, t+3)$ & $\operatorname{RET}(t, t+4)$ \\
\hline \multirow[t]{2}{*}{ Equal Weighted } & 35 & -0.0027 & 0.0018 & 0.0009 & 0.0000 \\
\hline & & -1.26 & 0.89 & 0.58 & -0.01 \\
\hline \multirow[t]{2}{*}{ Dollar Weighted } & 35 & -0.0015 & 0.0031 & 0.0011 & -0.0011 \\
\hline & & -0.20 & 0.60 & 0.31 & -0.36 \\
\hline \multirow[t]{2}{*}{ Percent Weighted } & 35 & -0.0066 & 0.0004 & 0.0025 & 0.0012 \\
\hline & & -1.27 & 0.09 & 0.76 & 0.46 \\
\hline
\end{tabular}

Note - Table 7 presents calendar time portfolio DGTW-adjusted returns following the purchase and sales of connected stocks. Each quarter the holdings of each connected stock are aggregated across all funds that hold the stock. The price change adjusted difference in holdings quarter to quarter is then used to identify a stock as having experienced buying or selling activity. To weight the holdings of each stock in the purchased and sales portfolio, the equal weighted, dollar weighted and percent weighted methodologies are used. Instead of weighting the absolute holdings the unit of weighting is the change in holdings. Panel A presents the returns of connected stocks following stock purchases. Panel B presents the returns of connected stocks following stock sales. Finally, Panel $\mathrm{C}$ analyzes the difference between the two portfolios. Average monthly returns are presented over the following 1,2,3 and 4 quarters after the stock purchase or sale (Column 1 through 4). T-Stats are reported below the coefficient estimates. 
Table 8: Connected Returns around Earnings Announcements: 2000-2008

\begin{tabular}{|c|c|c|c|c|c|c|}
\hline & $\mathrm{N}$ & $\begin{array}{l}\text { Connected Funds } \\
\text { Held Stocks }\end{array}$ & $\begin{array}{c}\text { Connected Funds } \\
\text { Unheld Stocks } \\
\text { Long/Short }\end{array}$ & $\begin{array}{c}\text { Unconnected Funds } \\
\text { All Stocks } \\
\text { Long/Short }\end{array}$ & $\begin{array}{c}\text { Unconnected Funds } \\
\text { Connected Stocks } \\
\text { Long/Short }\end{array}$ & $\begin{array}{c}\text { Connected Funds } \\
\text { Before/After Connection } \\
\text { Long/Short }\end{array}$ \\
\hline \multicolumn{7}{|c|}{ Earnings Announcement CAR } \\
\hline \multirow[t]{2}{*}{ Equal-Weighted } & 36 & 0.0130 & 0.0078 & 0.0084 & 0.0050 & 0.0067 \\
\hline & & 4.58 & 2.52 & 3.08 & 2.49 & 3.15 \\
\hline \multirow[t]{2}{*}{ Dollar-Weighted } & 36 & 0.0157 & 0.0155 & 0.0117 & 0.0084 & 0.0206 \\
\hline & & 4.39 & 3.81 & 3.28 & 2.86 & 3.69 \\
\hline \multirow[t]{2}{*}{ Percent-Weighted } & 36 & 0.0132 & 0.0094 & 0.0086 & 0.0066 & 0.0138 \\
\hline & & 4.57 & 2.99 & 3.23 & 3.41 & 4.26 \\
\hline
\end{tabular}

Note - Table 8 reports calendar time portfolio earnings announcement CAR. At the beginning of every calendar quarter, stocks in each mutual fund portfolio are assigned to one of five portfolios (connected held, connected not held, unconnected, unconnected funds-connected firms and connected funds-before/after connection). Quarterly earnings announcement CAR $[t=-1, t=+5]$ are computed for each stock each quarter. Abnormal returns are computed by adjusting returns using size adjusted portfolio. Portfolios are rebalanced every calendar quarter. To determine the return of each portfolio, the CAR of the stocks within each portfolio are equally weighted, weighted by the fund's dollar holdings (dollar holdings/total portfolio dollar holdings), weighted by their weight in their fund's portfolio (portfolio percent holding/aggregate percent holding), or weighted by the number of funds that hold (or don't hold) the stock. T-Stats are reported below the coefficient estimates. 
Table 9a: Earnings Announcement Surprises and Director Connections

\begin{tabular}{|c|c|c|c|}
\hline \multicolumn{4}{|c|}{ Probability of Positive Earnings Announcement Surprise } \\
\hline & (1) & $(2)$ & (3) \\
\hline \multirow[t]{2}{*}{ Connected Held } & 0.048 & & \\
\hline & 4.56 & & \\
\hline \multirow[t]{2}{*}{ Connected Not Held } & 0.016 & & \\
\hline & 2.05 & & \\
\hline \multirow[t]{2}{*}{ Connected Purchase } & & 0.057 & \\
\hline & & 3.64 & \\
\hline \multirow[t]{2}{*}{ Connected Sale } & & 0.019 & \\
\hline & & 1.16 & \\
\hline \multirow[t]{2}{*}{ Connected Not Traded } & & 0.054 & 0.054 \\
\hline & & 2.30 & 2.31 \\
\hline \multirow[t]{2}{*}{ Connected Initial Purchase } & & & 0.052 \\
\hline & & & 1.40 \\
\hline \multirow[t]{2}{*}{ Connnected Partial Purchase } & & & 0.058 \\
\hline & & & 3.38 \\
\hline \multirow[t]{2}{*}{ Connected Total Sale } & & & -0.039 \\
\hline & & & -1.07 \\
\hline \multirow[t]{2}{*}{ Connected Partial Sale } & & & 0.032 \\
\hline & & & 1.82 \\
\hline \multirow[t]{2}{*}{ Constant } & -0.039 & -0.049 & -0.048 \\
\hline & -1.71 & -2.12 & -2.09 \\
\hline $\mathrm{R}^{\wedge} 2$ & 0.017 & 0.018 & 0.018 \\
\hline Observations & 60935 & 59479 & 59479 \\
\hline Controls & Yes & Yes & Yes \\
\hline Fixed Effects & Quarter & Quarter & Quarter \\
\hline
\end{tabular}

Note - Table 9a presents pooled OLS quarterly regressions of earnings announcement surprises. The sample period is 2000 to 2008, and the units of observation are stock-quarter. An earnings announcement surprise is defined as the difference between a stock's actual quarterly earnings per share (EPS) value and the mean quarterly EPS analyst forecast as reported by the IBES database. If the actual EPS value is less than the forecast EPS value, the surprise is defined as negative. If the actual EPS value is more than $\$ 0.04$ greater than the forecast EPS value, the surprise is defined as positive. The dependent variable is a dummy variable indicating if the earnings announcement is positive. Column 1 tests if connected stocks being held and not held precede the earnings announcement surprises. Column 2 tests if connected stocks being purchased and sold by connected funds precede earnings announcement surprises. Lastly Column 3 tests if a connected stock being purchased for the first time or completely sold precedes earnings announcement surprises. Control variables include each stock's institutional holdings, market-to-book ratio quintile, In(marketcap) and asset growth. Quarter fixed effects are included. T-Stats are reported below the coefficient estimates. 
Table 9b: Earnings Announcement Surprises and Director Connections

\begin{tabular}{|c|c|c|c|}
\hline \multicolumn{4}{|c|}{ Probability of Negative Earnings Announcement Surprise } \\
\hline & $(1)$ & $(2)$ & (3) \\
\hline \multirow[t]{2}{*}{ Connected Held } & -0.016 & & \\
\hline & -1.32 & & \\
\hline \multirow[t]{2}{*}{ Connected Not Held } & 0.014 & & \\
\hline & 1.67 & & \\
\hline \multirow[t]{2}{*}{ Connected Purchase } & & -0.027 & \\
\hline & & -1.55 & \\
\hline \multirow[t]{2}{*}{ Connected Sale } & & 0.000 & \\
\hline & & -0.01 & \\
\hline \multirow[t]{2}{*}{ Connected Not Traded } & & 0.013 & 0.013 \\
\hline & & 0.49 & 0.49 \\
\hline \multirow[t]{2}{*}{ Connected Initial Purchase } & & & -0.038 \\
\hline & & & -0.93 \\
\hline \multirow[t]{2}{*}{ Connnected Partial Purchase } & & & -0.025 \\
\hline & & & -1.29 \\
\hline \multirow[t]{2}{*}{ Connected Total Sale } & & & 0.085 \\
\hline & & & 2.11 \\
\hline \multirow[t]{2}{*}{ Connected Partial Sale } & & & -0.020 \\
\hline & & & -1.03 \\
\hline \multirow[t]{2}{*}{ Constant } & 1.155 & 1.149 & 1.148 \\
\hline & 45.49 & 44.76 & 44.72 \\
\hline $\mathrm{R}^{\wedge} 2$ & 0.031 & 0.030 & 0.031 \\
\hline Observations & 60935 & 59479 & 59479 \\
\hline Controls & Yes & Yes & Yes \\
\hline Fixed Effects & Quarter & Quarter & Quarter \\
\hline
\end{tabular}

Note - Table $9 \mathrm{~b}$ presents pooled OLS quarterly regressions of earnings announcement surprises. The sample period is 2000 to 2008, and the units of observation are stock-quarters. An earnings announcement surprise is defined as the difference between a stock's actual quarterly earnings per share (EPS) value and the mean quarterly EPS analyst forecast as reported by the IBES database. If the actual EPS value is less than the forecast EPS value, the surprise is defined as negative. If the actual EPS value is more than $\$ 0.04$ greater than the forecast EPS value, the surprise is defined as positive. The dependent variable is a dummy variable indicating if the earnings announcement is negative. Column 1 tests if connected stocks being held and not held precede the earnings announcement surprises. Column 2 tests if connected stocks being purchased and sold by connected funds precede earnings announcement surprises. Lastly Column 3 tests if a connected stock being purchased for the first time or completely sold precedes earnings announcement surprises. Control variables include each stock's institutional holdings, market-to-book ratio quintile, $\ln$ (marketcap) and asset growth. Quarter fixedeffects are included. T-Stats are reported below the coefficient estimates. 
Table 10: Fund Flows to Connected Funds 2000-2008

\begin{tabular}{|c|c|c|c|}
\hline & Flow & $\mathrm{P}$ (Top 20\%) & $\mathrm{P}$ (Bottom 20\%) \\
\hline \multirow[t]{2}{*}{ \# of Connections } & 0.00288 & 0.00644 & 0.00026 \\
\hline & 5.31 & 4.59 & 0.18 \\
\hline \multirow[t]{2}{*}{ Lag TNA } & 0.00495 & -0.03823 & -0.00765 \\
\hline & -16.47 & -20.96 & -3.73 \\
\hline \multirow[t]{2}{*}{ Lag Return } & 0.07164 & 0.09574 & -0.08200 \\
\hline & 1.73 & 2.02 & -1.82 \\
\hline \multirow[t]{2}{*}{ Flow to Style } & 0.17002 & 0.16140 & -0.08029 \\
\hline & 5.79 & 6.42 & -5.56 \\
\hline \multirow[t]{2}{*}{ Constant } & 0.04683 & 0.28114 & 0.30150 \\
\hline & 7.55 & 14.38 & 15.59 \\
\hline$R^{\wedge} 2$ & 0.1471 & 0.065 & 0.0135 \\
\hline Observations & 22135 & 22152 & 22152 \\
\hline \multicolumn{4}{|c|}{ Panel B: Held and Unheld Director Connections and Fund Flow } \\
\hline & Flow & $\mathrm{P}$ (Top 20\%) & $\mathrm{P}$ (Bottom 20\%) \\
\hline \multirow[t]{2}{*}{ \# of Held Connections } & 0.04569 & 0.01217 & -0.01545 \\
\hline & 4.19 & 2.52 & -3.80 \\
\hline \multirow[t]{2}{*}{ \# of Unheld Connections } & 0.01098 & 0.00563 & 0.00249 \\
\hline & 3.47 & 3.66 & 1.54 \\
\hline \multirow{2}{*}{ Lag TNA } & -0.08399 & -0.03869 & -0.00638 \\
\hline & -16.97 & -20.94 & -3.06 \\
\hline \multirow[t]{2}{*}{ Lag Return } & 0.12455 & 0.09589 & -0.08239 \\
\hline & 1.73 & 2.01 & -1.82 \\
\hline \multirow[t]{2}{*}{ Flow to Style } & 0.98575 & 0.16152 & -0.08062 \\
\hline & 5.80 & 6.42 & -5.56 \\
\hline \multirow[t]{2}{*}{ Constant } & 0.36728 & 0.28374 & 0.29437 \\
\hline & 7.87 & 14.45 & 15.12 \\
\hline $\mathrm{R}^{\wedge} 2$ & 0.1475 & 0.06511 & 0.0144 \\
\hline Observations & 22135 & 22152 & 22152 \\
\hline
\end{tabular}

Note - Table 10 present the results of a pooled OLS regression to test if director connections impact annual AUM fund flows. Fund Flow is defined as the changes in a fund's Total Net Assets (TNA) after adjusting for the returns of the fund. The independent variable of interest is the number of firms each fund is connected to. A set of controls are included in order to isolate the effect of the connection. These controls include a variable for the fund's size, past returns and style. Year fixed-effects are included and standard errors are clustered at the fund level. The dependent variable is the fund's annual fund flow (column 1), the probability the fund is in the highest quintile of fund flow for the year (column 2), and the probability the fund is in the lowest quintile of fund flow for the year (column 3). Panel A of Table 1 focuses on all connections, while panel B distinguishes between held and unheld connections. T-stats are presented below the coefficient estimate of each variable. 